\title{
The challenges of using a copper fluorescent sensor (CS1) to track intracellular distributions of copper in neuronal and glial cells $\dagger$
}

\author{
Katherine A. Price, ${ }^{a}$ James L. Hickey, ${ }^{b c}$ Zhiguang Xiao, ${ }^{b c}$ Anthony G. Wedd, ${ }^{b c}$ Simon A. James, ${ }^{d}$ \\ Jeffrey R. Liddell, ${ }^{a}$ Peter J. Crouch, ${ }^{a}$ Anthony R. White ${ }^{* a}{ }^{* a}$ and Paul S. Donnelly ${ }^{*}{ }^{* b c}$
}

Received 31st March 2012, Accepted 10th June 2012

DOI: $10.1039 / \mathrm{c} 2 \mathrm{sc20397a}$

Copper is an essential biometal involved in critical cell functions including respiration. However, the mechanisms controlling its sub-cellular localization during health and disease remain poorly understood. This is partially due to the difficulty of detecting a metal ion that is bound tightly to metallo-chaperone and detoxification molecules in the cell. A BODIPY-based Cu fluorescent probe $\mathrm{CS} 1(\mathrm{Cu}$ sensor 1) has been applied in innovative attempts to visualize monovalent $\mathrm{Cu}$ pools within cells (Zeng et al., J. Am. Chem. Soc., 2006, 128, 10-11). Inspired by this work, we sought to use CS1 to identify sub-cellular localization of $\mathrm{Cu}$ delivered to M17 neuronal or U87MG glial cells by a cellpermeable bis(thiosemicarbazonato) $\mathrm{Cu}$ (II) complex, $\mathrm{Cu}^{\mathrm{II}}(\mathrm{gtsm})$. This complex increases cellular $\mathrm{Cu}$ concentrations by factors of 10-100 when compared to treatment with equivalent concentrations of $\mathrm{CuCl}_{2}$ (Donnelly et al., J. Biol. Chem., 2008, 283, 4568-4577). However, we were unable to identify any specific increase in $\mathrm{CS} 1$ fluorescence in neurons or glia treated with $\mathrm{CuCl}_{2}$ or with $\mathrm{Cu}^{\mathrm{II}}(\mathrm{gtsm})$, despite controls revealing a large increase in total cellular $\mathrm{Cu}$ with the latter treatment. Further in vitro characterization of CS1 suggests that, consistent with its relatively weak affinity for $\mathrm{Cu}^{\mathrm{I}}\left(K_{\mathrm{D}} \approx\right.$ $\left.10^{-11} \mathrm{M}\right)$, it is unlikely to compete with endogenous proteins with sub-picomolar affinities, nor with glutathione, the endogenous redox buffer essential for functional maintenance of many proteins, including those that bind $\mathrm{Cu}^{\mathrm{I}}$. Moreover, we show that $\mathrm{CS} 1$ is localized predominantly to lysosomes and that the observed background fluorescence may be attributed to increased concentrations of apo$\mathrm{CS} 1$ in this organelle or to the probe gaining access to $\mathrm{Cu}^{\mathrm{I}}$ made available via recycling of nutrient $\mathrm{Cu}$ in the acidic lysosome. It was possible to observe a consistent increase in CS1 fluorescence in neuronal cells exposed to stress. For example, treatment with buthionine sulfoximine decreased cellular glutathione levels and led to enhanced CS1 fluorescence, but the total cellular Cu levels did not correlate with the increased fluorescence. In addition, cells treated with reagents that are known to alter cellular $\mathrm{pH}$ homeostasis provided an enhanced fluorescence. Our findings demonstrate that the source of enhanced CS1 fluorescence in $\mathrm{Cu}$-supplemented cells must be interpreted with caution. It may be a consequence of altered cell $\mathrm{pH}$, compromised vesicle maturation, increased CS1 uptake and/or trapping of CS1 in the lysosomal compartment.

\footnotetext{
${ }^{a}$ Department of Pathology, The University of Melbourne, 3010, and Mental Health Research Institute, Parkville, 3052, Victoria, Australia. E-mail: arwhite@unimelb.edu.au; Fax: +61 (3) 8344 4004; Tel: +61 (3) 8344 1805

${ }^{b}$ Bio21 Molecular Science and Biotechnology Institute, The University of Melbourne, Parkville,Victoria, 3052, Australia.E-mail: pauld@unimelb. edu.au; Tel: +61 (3) 83442399

'School of Chemistry, The University of Melbourne, Victoria, 3010, Australia

${ }^{d}$ CSIRO Materials Science and Engineering, Clayton, Victoria, Australia and the CSIRO Preventive Health Flagship

$\dagger$ Electronic supplementary information (ESI) available: Evaluation of $\mathrm{CS} 1$ as a $\mathrm{Cu}^{\mathrm{I}}$ probe in cell-free experiments. See DOI: 10.1039/c2sc20397a \$ These authors contributed equally.
}

\section{Introduction}

Copper is an essential element in biological systems, being a critical component of many enzymes and, in particular, of mitochondrial cytochrome $\mathrm{c}$ oxidase. Its $\mathrm{Cu}^{\mathrm{II}} / \mathrm{Cu}^{\mathrm{I}}$ redox couple drives its role in cellular metabolism, but this reactivity also means that, when uncontrolled, $\mathrm{Cu}$ ions can generate damaging reactive oxygen species. ${ }^{1} \mathrm{Cu}^{\mathrm{II} / \mathrm{I}}$ also has the potential to bind adventitiously to protein surfaces and to displace other biometals from their active sites. ${ }^{2}$ In mitigation, cells have developed elaborate systems to manage this essential nutrient. ${ }^{3}$

Upon uptake by the $\mathrm{Cu}$ transporter $\mathrm{Ctr} 1$ at the mammalian plasma membrane, $\mathrm{Cu}^{\mathrm{I}}$ is trafficked to a number of cellular locations including the mitochondria, endoplasmic reticulum, 
trans-Golgi network and the cytosolic enzyme superoxide dismutase (SOD). This is effected by specifically evolved metallochaperones, including Atox1 and the $\mathrm{Cu}$ chaperone for SOD. ${ }^{3,4}$ Although there appears to be essentially no free $\mathrm{Cu}$ in eukaryotic cells, ${ }^{5-7}$ it appears that a pool of bioavailable $\mathrm{Cu}$ is maintained to allow flow between proteins and metallo-chaperones, depending on need. If $\mathrm{Cu}$ levels are deficient, the metal can be mobilized from these pools and, if excessive, stored in metallothionein or eliminated from the cell by trafficking of the $\mathrm{Cu}$ transporters ATP7a/ATP7b from the trans-Golgi membranes to the plasma membrane. ${ }^{8}$

Investigation of the levels and localization of these putative 'labile' $\mathrm{Cu}$ pools ${ }^{9-12}$ is difficult due to the presence of multiple $\mathrm{Cu}$ binding and detoxification proteins. A novel fluorophore CS1 (Cu sensor 1) specific for $\mathrm{Cu}^{\mathrm{I}}$ has been developed (Fig. 1). ${ }^{10,13}$ The sensing ligand is based on a thioether-rich $\mathrm{NS}_{4}$ binding site and is attached to a borondipyrromethene fluorophore (BODIPY). Binding of $\mathrm{Cu}^{\mathrm{I}}$ results in a ten-fold enhancement of fluorescence intensity over the (significant) intensity of the free fluorophore. ${ }^{10,13}$ The original report demonstrated a highly elevated fluorescence signature for CS1 upon exposure of HEK293 human kidney cells to $\mathrm{CuCl}_{2} \cdot{ }^{10}$ Other versions of the probe have been developed with improved spectroscopic or targeting properties, but the sensor component remains the same ${ }^{11,12,14}$.

CS1 was applied here to investigate the localization of possible 'labile' $\mathrm{Cu}$ pools in neuronal and glial cell lines treated with both $\mathrm{CuCl}_{2}$ and a bis(thiosemicarbazonato)Cu(II) complex, $\mathrm{Cu}^{\mathrm{II}}$ (gtsm) (Fig. 1). The latter family of complexes is useful in this context as they are cell permeant and able to rapidly increase $\mathrm{Cu}$ levels by factors of ten to one hundred compared to treatment with comparable concentrations of $\mathrm{CuCl}_{2} \cdot{ }^{15,16} \mathrm{In}$ addition, minor changes to the structure of the ligand backbone result in significant differences in behavior under normoxic and hypoxic conditions, allowing a degree of control over metal ion release inside cells. ${ }^{17-20}$

Using confocal fluorescence microscopy, this study was unable to identify any specific increase in CS1 fluorescence in neuronal- or glial-like cells or additional cell lines treated with $\mathrm{CuCl}_{2}$ or with the $\mathrm{Cu}^{\mathrm{II}}(\mathrm{gtsm})$ complex, despite atomic absorption spectroscopy

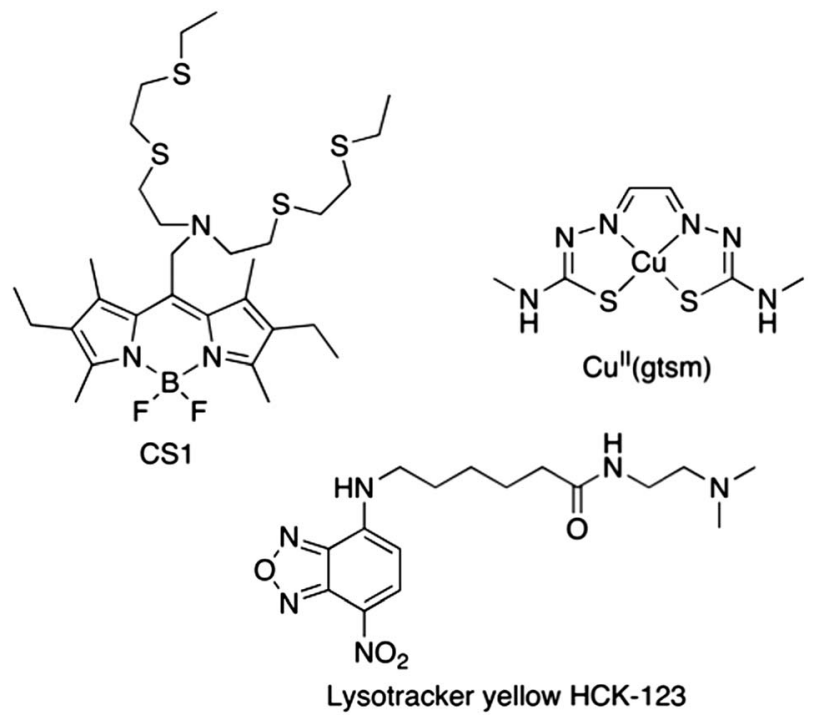

Fig. 1 Structures of CS1, Cu${ }^{\mathrm{II}}(\mathrm{gtsm})$ and Lysotracker yellow HCK-123.
(AAS) revealing a large increase in total cellular $\mathrm{Cu}$ with the latter treatment. CS1 appears to localize predominantly to the lysosome. Cell-free testing revealed that, at physiological $\mathrm{pH}, \mathrm{CS} 1$ cannot compete for $\mathrm{Cu}^{\mathrm{I}}$ with metallo-chaperones of sub-picomolar affinity, nor even with glutathione $(\mathrm{GSH})$ at the relative concentrations and $\mathrm{pH}$ of the cytosol. There appears to be no intracellular labile $\mathrm{Cu}$ pool which is bound weakly enough for CS1 to sense, at least in the neuronal and glial cells used in this study. Fluorescent enhancement was seen in cells subjected to redox or acid-base stress. These findings indicate that the use of CS1 to detect intracellular $\mathrm{Cu}$ needs to be approached with caution.

\section{Methods}

\section{Materials}

$\mathrm{Cu}^{\mathrm{II}}$ (gtsm) was synthesized as described previously. ${ }^{15,21-23} \mathrm{CS} 1$ was prepared using previously reported procedures. ${ }^{10,13}$

\section{Methods}

Cell culture. The cells used in this study were human-derived U87MG glioblastoma, BE (2)-M17 neuroblastoma and SHSY5Y neuroblastoma cell lines, as well as HEK293 and CHO epithelial cells. They were passaged and maintained in DMEM/ F12 plus 10\% FBS (U87MG, SH-SY5Y cells), OptiMem plus $10 \%$ FBS (M17 cells) or DMEM plus 20\% FBS (HEK293, CHO cells). Cells were grown in $5 \% \mathrm{CO}_{2}$ at $37^{\circ} \mathrm{C}$ and passaged at $1: 5-$ $1: 10$ until $70-90 \%$ confluent.

Treatment of cells with $\mathrm{Cu}$. Cells were grown in 6-well plates or $100 \mathrm{~mm}$ dishes until $\sim 80 \%$ confluent. $\mathrm{CuCl}_{2}$ or $\mathrm{Cu}^{\mathrm{II}}(\mathrm{gtsm})$ from stock solution (10 $\mathrm{mM}$ in DMSO) was applied to serum-free medium at the indicated concentrations and times. Where indicated, cells were pre-treated with bafilomycin (Baf) or buthionine sulfoximine (BSO). Cells were washed twice with PBS after the treatment to remove extra-cellular $\mathrm{Cu}$ before collection or fixation. For CS-1 fluorescence, a $1 \mathrm{mM}$ stock concentration of CS1 prepared in DMSO was added to the cells for the last $5 \mathrm{~min}$ of the total $\mathrm{CuCl}_{2}$ or $\mathrm{Cu}^{\mathrm{II}}(\mathrm{gtsm})$ treatment period. A final working concentration of either $500 \mathrm{nM}$ or $5 \mu \mathrm{M}$ was used, unless otherwise stated. After the 5 min incubation period, the added $\mathrm{Cu}$ and CS1 were aspirated from the treated wells and cells were rinsed with PBS ( $\times 2$ for $5 \mathrm{~min}$ ) before fixation with $4 \%$ paraformaldehyde.

Confocal microscopy. Where indicated, cells were co-treated with Lysotracker Yellow (Fig. 1) or $\mathrm{NBDC}_{6}$-ceramide to detect lysosomes and Golgi, respectively.

Live cell microscopy. Cells were grown in chamber slides until approximately $70 \%$ confluent and treated as necessary. After the treatment incubation period, the slides were placed in the Leica DMI6000 B widefield microscope with integrated temperature and $\mathrm{CO}_{2}$ controller. Images were collected using a Leica DFC360FX CCD camera.

Atomic absorption spectroscopy (AAS). After treatment, cells were washed as above and collected cell pellets were re-suspended in acid (concentrated ultra-pure nitric acid (500 $\mu \mathrm{l}$; Aristar, BDH) in $0.5-2.5 \mathrm{ml}$ de-ionized $\mathrm{H}_{2} \mathrm{O}$ ). Samples were then heated 
in a heating block for $3 \mathrm{~h}$ at $65^{\circ} \mathrm{C}$. Measurements were made using a Varian SpectrAA 800 instrument under operating conditions suitable for routine multi-element analysis. Several blanks and multiple $\mathrm{Cu}$ standards were routinely measured with each run. Results were expressed as micromole $\mathrm{Cu}$ per litre of sample $\left(\mu \mathrm{mol} \mathrm{L}{ }^{-1}\right)$. These were converted to $\mu \mathrm{g} \mathrm{Cu}$ per mg of protein based on the protein concentration of parallel cultures.

X-ray fluorescence microscopy (XFM). For XFM experiments, cells were grown on silicon nitride windows in 24-well plates until approximately $70 \%$ confluent. They were then treated for $30 \mathrm{~min}$ with either $5 \mu \mathrm{M} \mathrm{CuCl}_{2}$ or $\mathrm{Cu}^{\mathrm{II}}(\mathrm{gtsm})$ in $\mathrm{DMSO} /$ culture media solution or DMSO vehicle/culture media alone. The cells were then washed twice with PBS before fixation using paraformaldehyde (PFA; 4\% v/v) for $10 \mathrm{~min}$ at RT. This solution was subsequently rinsed off the windows with PBS twice, with a final rinse with doubly de-ionized $\mathrm{H}_{2} \mathrm{O}$ before being allowed to dry in air. The dried specimens were then transported (on desiccant) to the Australian Synchrotron facility (AS; Clayton, Australia) for imaging. A monochromatic $12.73 \mathrm{keV}$ X-ray beam focused to a spot size of $\sim 1.5 \mu \mathrm{m}$ in diameter using the Kirkpatrick-Baez mirror microprobe on the XFM beamline at the AS was used. This incident energy was chosen to excite elemental fluorescence from elements with a $Z<30$. The trace metal distributions were mapped by raster scanning the specimen through the X-ray focus with a pixel size of $1.25 \mu \mathrm{m}^{2}$ (well-matched to the beam size) and the resulting full-spectral images obtained using the Maia detector system. System calibration and spectral deconvolution of the Maia data was performed as described elsewhere. ${ }^{24,25}$ Briefly, the single photon fluorescence data was reduced for analysis using the dynamic analysis method as utilized by the GeoPIXE software suite. ${ }^{26}$ Absorption effects at the lowest atomic number element that can be accessed using the Maia detector (potassium $\mathrm{K}_{\alpha}$ radiation) are negligible for these specimens, assuming the typical composition and density $\left(1.2 \mathrm{~g} \mathrm{~cm}^{-3}\right)$ of biological material. ${ }^{27}$ The calculated values were then normalized to the ratio of cellular $\mathrm{K}^{\mathrm{I}} \mathrm{Zn}^{\mathrm{II}}$.

Measurement of cellular GSH levels. Cells were grown in 6-well plates and treated with $\mathrm{CuCl}_{2}$ or $\mathrm{Cu}^{\mathrm{II}}(\mathrm{gtsm})$ as indicated. They were scraped into treatment media and collected by centrifugation at $720 \mathrm{~g}$ for $3 \mathrm{~min}$. The supernatant was discarded and each cell pellet homogenized with salicylic acid $(2.5 \%(v / v) ; 100 \mu \mathrm{L})$. Homogenized cell samples were then centrifuged again at $720 \mathrm{~g}$ for $3 \mathrm{~min}$. Parallel samples were re-suspended in Phosphosafe extraction reagent $(10 \mu \mathrm{L})$ so that the protein concentration of the samples could be determined using the bicinchoninate (Bca) protein assay when needed. Glutathione standards $(0,0.2,0.4$, $0.6,0.8$ and $1 \mu \mathrm{M}$ in $10 \mu \mathrm{L}$ ) or supernatant from the homogenized samples $(10 \mu \mathrm{L})$ were then added to wells on a clear-

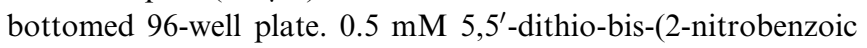
acid) (DTNB), $0.01 \mathrm{U}$ glutathione reductase and $0.2 \mathrm{mM}$ NADPH were added to $200 \mu \mathrm{L}$ final volume. The plate was incubated at $37^{\circ} \mathrm{C}$ for $5 \mathrm{~min}$ and the absorbance read at $412 \mathrm{~nm}$ in a WALLAC Victor ${ }^{2}$ plate reader. The glutathione content of

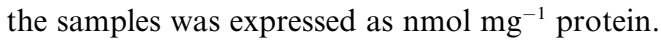

Statistical analysis. All data described in graphical representations are given as the mean value \pm standard error of the mean
(SEM), from a minimum of three experiments, unless stated. Results were analyzed using two-tailed Student's $t$-tests.

Evaluation of $\mathrm{CS} 1$ as a $\mathrm{Cu}^{\mathrm{I}}$ probe in cell-free competition experiments. Binding of $\mathrm{Cu}^{\mathrm{I}}$ to $\mathrm{CS} 1$ is characterized by an increase in absorbance around $540 \mathrm{~nm}\left(\Delta \varepsilon_{540}=\sim 2.4 \times 10^{4} \mathrm{M}^{-1}\right.$ $\left.\mathrm{cm}^{-1}\right)$ in the electronic spectrum and by a large enhancement of fluorescence intensity upon excitation at this wavelength. ${ }^{10,13}$ Consequently, $\mathrm{Cu}^{\mathrm{I}}$ sensing by $\mathrm{CS} 1$ in the presence of competing ligands can be monitored with either approach. The representative competing ligands selected included molecules of low molar mass (Bca, GSH) and metallo-chaperone proteins (CopK, Atox1). These competing ligands and their $\mathrm{Cu}^{\mathrm{I}}$ complexes have little absorbance in their visible spectra except for the $\mathrm{Cu}^{\mathrm{I}}-\mathrm{Bca}$ complex $\left[\mathrm{Cu}^{\mathrm{I}}(\mathrm{Bca})_{2}\right]^{3-}$. However, the molar absorptivity of this complex at $540 \mathrm{~nm}\left(\varepsilon_{540}=6.3 \times 10^{3} \mathrm{M}^{-1} \mathrm{~cm}^{-1}\right)$ is only about a quarter of $\Delta \varepsilon_{540}$ for the $\mathrm{Cu}^{\mathrm{I}}$ binding to apo-CS1 (Fig. S1A $\dagger$ ) and does not alter the detection of $\mathrm{Cu}^{\mathrm{I}}$ binding to $\mathrm{CS} 1$. The experiments were performed under anaerobic conditions by titration of either $\left[\mathrm{Cu}^{\mathrm{I}}(\mathrm{MeCN})_{4}\right]^{+}$or $\mathrm{CuSO}_{4}$ solutions (both $\sim 40 \mu \mathrm{M}$ ) into a CS1 solution containing the competing ligand and an appropriate reductant (hydroxylamine $\mathrm{NH}_{2} \mathrm{OH}$ or ascorbate) or by titration of the competing ligand into a solution of $\mathrm{Cu}^{\mathrm{I}}-\mathrm{CS} 1$. The competing processes were monitored by changes in the fluorescence emission and/or electronic spectra and the data analyzed by techniques reported previously. ${ }^{28,29}$

The complex $\mathrm{Cu}^{\mathrm{I}}-\mathrm{CS} 1$ was generated in situ by quantitative titration of $\mathrm{Cu}^{\mathrm{II}}$ into apo-CS1 solution in the presence of an appropriate reductant $\left(\mathrm{NH}_{2} \mathrm{OH}\right.$ at $\mathrm{pH} 6.0-7.4$ or ascorbate at $\mathrm{pH}$ 4.0). Concentrations of apo-CS1 solutions in MOPS buffer were estimated approximately using $\varepsilon_{540}=2.5 \times 10^{4} \mathrm{M}^{-1} \mathrm{~cm}^{-1}$ and calibrated further via titration with a $\mathrm{Cu}^{\mathrm{I}}$ standard solution or a $\mathrm{Cu}^{\mathrm{II}}$ standard solution in the presence of $\mathrm{NH}_{2} \mathrm{OH}(100 \mu \mathrm{M}$ ) (see Figs S1A and $7 \mathrm{~A} \dagger$ ). Both Bca and GSH were purchased from Sigma and used as received. The Bca concentration was calibrated by titration with a $\mathrm{Cu}^{\mathrm{II}}$ standard in the presence of $\mathrm{NH}_{2} \mathrm{OH}^{28}$ The GSH concentration was determined by DNTB. ${ }^{30}$ Atox1 and CopK proteins were expressed and purified as reported. ${ }^{29,31}$ Prior to the experiments, the Atox 1 protein was fully reduced by incubation overnight with dithiothreitol (DTT) and excess DTT was then removed by passing the solution through a desalting column in an anaerobic glove box $\left(\left[\mathrm{O}_{2}\right]<2\right.$ ppm). The thiol content was determined with Ellman's reagent and the high affinity $\mathrm{Cu}^{\mathrm{I}}$-binding capacity evaluated with chromophoric reagent $\left[\mathrm{Cu}^{\mathrm{I}}(\mathrm{Bca})_{2}\right]^{3-}$ according to the reported procedures. ${ }^{29}$ As expected, the Atox1 protein contained three equivalents of thiol and was able to remove one equivalent of $\mathrm{Cu}^{\mathrm{I}}$ from $\left[\mathrm{Cu}^{\mathrm{I}}(\mathrm{Bca})_{2}\right]^{3-}$.

\section{Results and discussion}

\section{Elevated CS1 fluorescence was observed in Cu-supplemented HEK293 cells}

To mesh our techniques with those of the original work, ${ }^{10,13} \mathrm{CS} 1$ was applied to the same model system, namely $\mathrm{CuCl}_{2}$-treated HEK293 cells. Cells were treated with $\mathrm{CuCl}_{2}(100 \mu \mathrm{M})$ for $6 \mathrm{~h}$ and CS1 $(5 \mu \mathrm{M})$ was added for the last $5 \mathrm{~min}$ of the total treatment time. Analysis by confocal fluorescence microscopy (Ex 
$543 \mathrm{~nm} /$ Em 550-650 nm) revealed enhanced fluorescence intensity compared to DMSO-treated control cells (Fig. 2A). The increase in intracellular fluorescence was consistent with the original observations. ${ }^{10}$ Enhanced fluorescence intensities were also observed in cells that had been treated with $\mathrm{Cu}^{\mathrm{II}}$ (gtsm) ( 5 $\mu \mathrm{M}$ ) for $30 \mathrm{~min}$ (Figs 1 and 2A), which is consistent with our previous studies demonstrating that this complex will be taken up rapidly by the cells, is reduced and then transfers its bound $\mathrm{Cu}$ as $\mathrm{Cu}^{\mathrm{I}}$ into the $\mathrm{Cu}$-binding environment of the cell. ${ }^{15,16}$

Parallel estimation of total cellular $\mathrm{Cu}$ by AAS (Fig. 2B) did not correlate with the relative fluorescence enhancements induced by $\mathrm{CuCl}_{2}$ and $\mathrm{Cu}^{\mathrm{II}}(\mathrm{gtsm})$. This was interpreted as the CS1 signal saturating at the level of $\mathrm{Cu}^{\mathrm{I}}$ induced by the $\mathrm{CuCl}_{2}$ treatment. The CS1: $\mathrm{Cu}$ binding stoichiometry is $1: 1^{10}$

\section{Elevated CS1 fluorescence was not observed in Cu-supplemented neuronal M17 or U87MG glial cells}

Our interest in $\mathrm{Cu}$ flux in neuronal cells led us to extend the study to the M17 neuronal cell line. This cell type was chosen due to our interest in the potential neuroprotective action of $\mathrm{Cu}^{\mathrm{II}}(\mathrm{gtsm})$ and related complexes, ${ }^{15,16,32-34}$ and we have recently reported on uptake and trafficking of these complexes in M17 cells. ${ }^{32}$ The M17 cell line appears to be a useful model cell system in the present context.
Upon treatment with $\mathrm{CuCl}_{2}$ or $\mathrm{Cu}^{\mathrm{II}}$ (gtsm) followed by $\mathrm{CS} 1$, a dose-dependent change in CS1 fluorescence was not observed for any case over a $30 \mathrm{~min}$ treatment period (Fig. 3A and B). Interestingly, a punctate, vesicular-like staining pattern in the cytosol, consistent with lysosomal morphology, was a consistent feature of all CS1-treated M17 cells, including the vehicle controls.

A number of additional controls were undertaken to confirm this unexpected result:-

(a) To ensure that the lack of response in CS1 fluorescence was not due to impaired uptake of $\mathrm{Cu}$ by the neuronal cell line, total cellular $\mathrm{Cu}$ levels were examined in parallel using AAS. This approach revealed significant dose-dependent increases in cellular $\mathrm{Cu}$ with all treatments and again, as expected, $\mathrm{Cu}^{\mathrm{II}}(\mathrm{gtsm})$ induced a significantly greater increase in cellular $\mathrm{Cu}$ level than $\operatorname{did} \mathrm{CuCl}_{2}$ (Fig. 3C). However, it should be noted that the increased total cellular $\mathrm{Cu}$ level does not necessarily accurately represent the limited pool of $\mathrm{Cu}$ available for interaction with CS1.

(b) A U87MG glial cell line ${ }^{31}$ was examined to test if the lack of $\mathrm{Cu}$-associated enhancement in CS1 fluorescence was specific to M17 cells. The same treatment protocol as used for HEK293 cells (Fig. 2A) was applied to the U87MG cells $\left(100 \mu \mathrm{M} \mathrm{CuCl}_{2}\right.$ for $6 \mathrm{~h}$ with $5 \mu \mathrm{M} \mathrm{CS} 1$ for the last $5 \mathrm{~min})$. However, changes to CS1 fluorescence were not observed (Fig. 3D). To confirm that the lack of enhanced CS1 fluorescence with $\mathrm{Cu}$ supplementation was

A
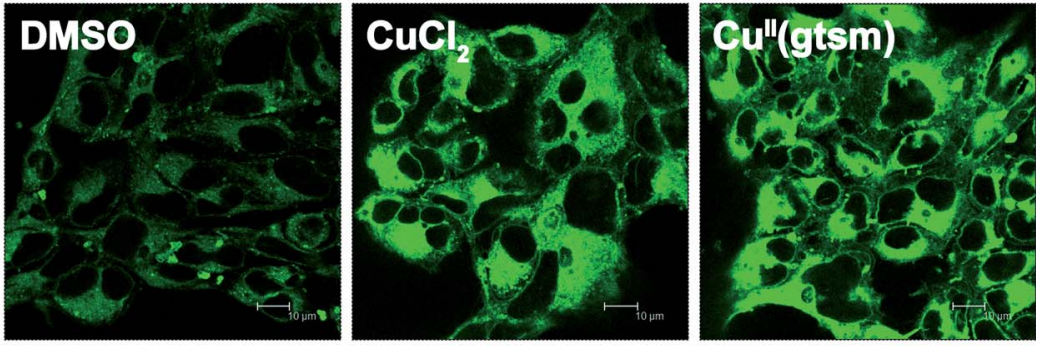

B

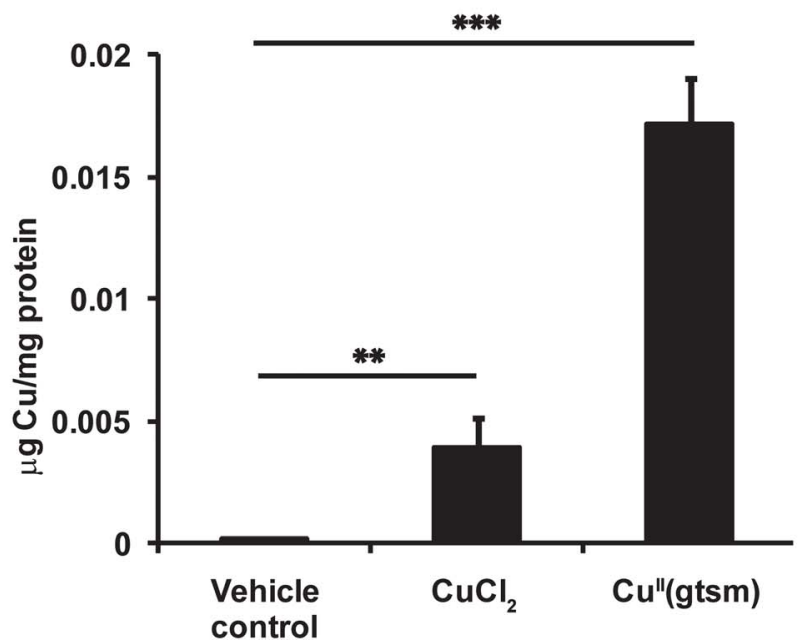

Fig. 2 Fluorescent staining of CS1 in HEK293 cells in the presence and absence of $\mathrm{Cu}$ (A). Cells were treated with $\mathrm{DMSO}$ as a vehicle control, $\mathrm{CuCl}$ 2 $(100 \mu \mathrm{M})$ for $6 \mathrm{~h}$, or $\mathrm{Cu}^{\mathrm{II}}(\mathrm{gtsm})(5 \mu \mathrm{M})$ for $30 \mathrm{~min}$. For all treatments $\mathrm{CS} 1(5 \mu \mathrm{M})$ was added for $5 \mathrm{~min}$ at the end of the treatment period. Cells were fixed with 4\% PFA and examined by confocal microscopy. Increased fluorescence was observed in cultures treated with $\mathrm{CuCl}_{2}$ and $\mathrm{Cu}^{\mathrm{II}}(\mathrm{gtsm})$. Parallel $\mathrm{AAS}$ showed a significant increase in cellular $\mathrm{Cu}$ concentration in $\mathrm{Cu}$-supplemented cells compared to non-supplemented cells $(\mathrm{B})(* * p<0.01, * * * p<0.001$ compared to vehicle control). Scale bars represent $10 \mu \mathrm{m}$ for all images. 
A

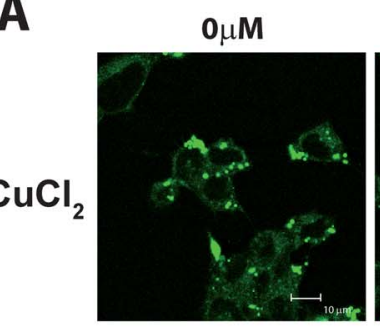

B

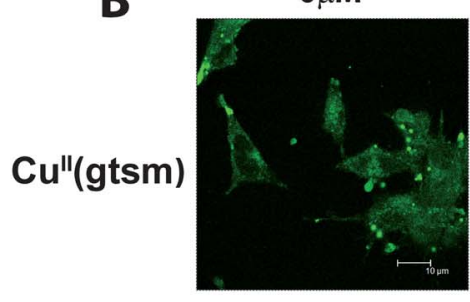

C

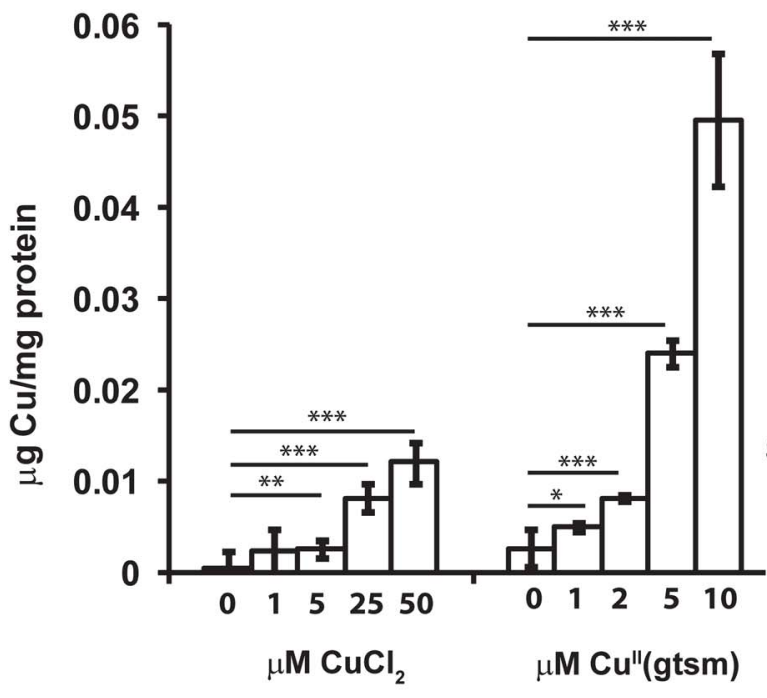

$5 \mu \mathrm{M}$

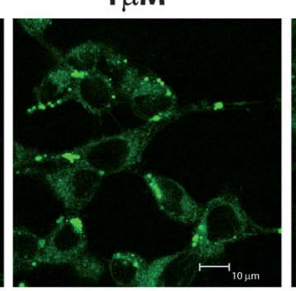

$\mathbf{1} \mu \mathbf{M}$

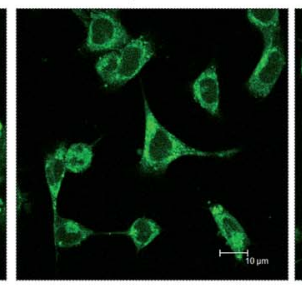

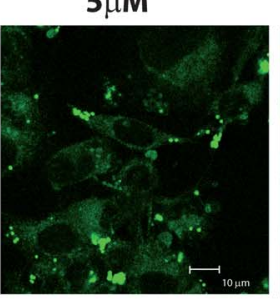

$2 \mu \mathrm{M}$

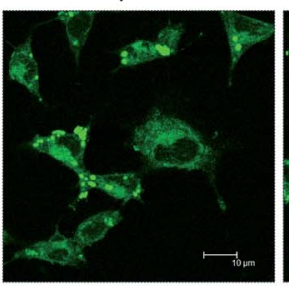

$25 \mu M$

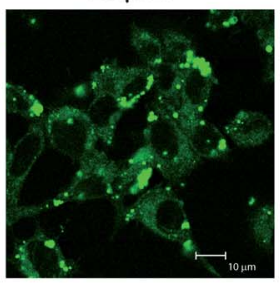

$5 \mu \mathrm{M}$

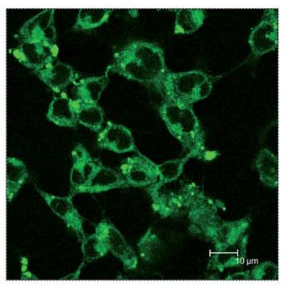

$50 \mu \mathrm{M}$

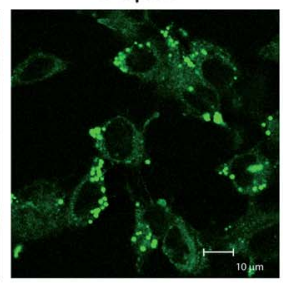

$10 \mu \mathrm{M}$

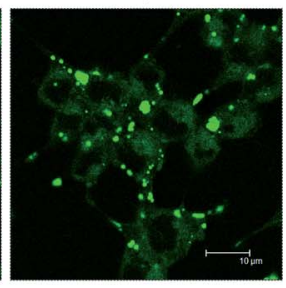

D

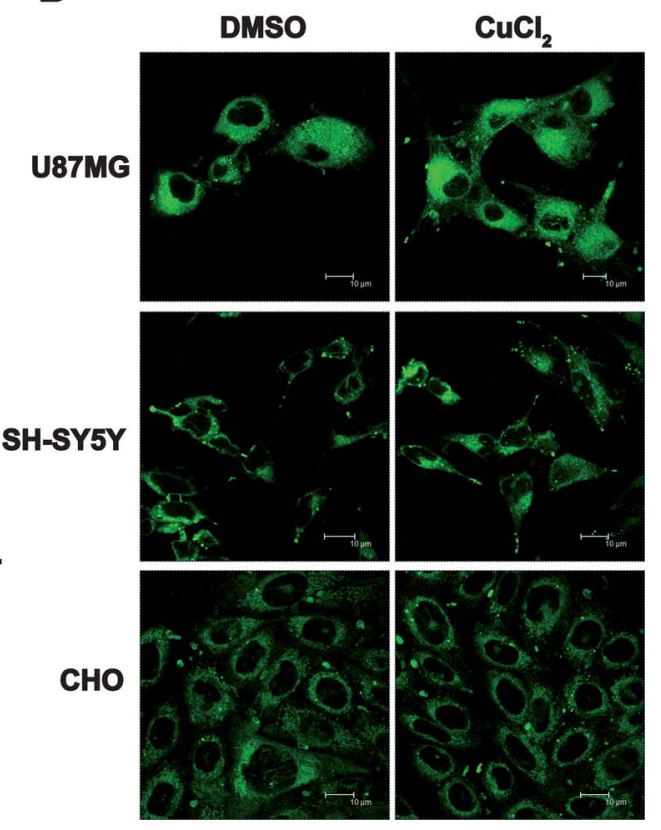

Fig. $3 \mathrm{CS} 1$ fluorescence did not increase with increasing concentrations of $\mathrm{CuCl}_{2}$ or $\mathrm{Cu}^{\mathrm{II}}(\mathrm{gtsm})$ in $\mathrm{M} 17$ cells. Cells were treated with increasing concentrations of $\mathrm{CuCl}_{2}(\mathrm{~A})$, or $\mathrm{Cu}^{\mathrm{II}}(\mathrm{gtsm})(\mathrm{B})$ for $30 \mathrm{~min}$ and $\mathrm{CS} 1(5 \mu \mathrm{M})$ was added for $5 \mathrm{~min}$. Cells were fixed with $4 \%$ PFA and examined by confocal microscopy. No increase in fluorescence was observed in cultures treated with $\mathrm{CuCl}_{2}$ or $\mathrm{Cu}^{\mathrm{II}}(\mathrm{gtsm})$ at any concentration. Parallel measurement of cellular $\mathrm{Cu}$ levels by AAS showed a dose-dependent increase in $\mathrm{Cu}$ in $\mathrm{CuCl}_{2}$ and $\mathrm{Cu}^{\mathrm{II}}(\mathrm{gtsm})$-treated cells $(\mathrm{C}) .{ }^{*} p<0.05, * * p<0.01, * * * p<0.001$ compared to vehicle control. (D) CS1 fluorescence was not enhanced in U87MG glial cells, SH-SY5Y neuronal-like cells or CHO epithelial cells supplemented with $\mathrm{CuCl}_{2}$. Cells were treated with $\mathrm{CuCl}_{2}(100 \mu \mathrm{M})$ for $6 \mathrm{~h}$. CS1 $(5 \mu \mathrm{M})$ was added for the last 5 min of treatment. Cells were fixed with $4 \%$ PFA and examined for CS1 fluorescence by confocal microscopy. This treatment matched the original treatment protocol for HEK293 cells as shown in Fig. 2A. Scale bars represent $10 \mu \mathrm{m}$.

not a product of the cell lines examined, we extended the analysis to include SH-SY5Y neuronal-like cells and CHO epithelial cells. However, again, no evidence of enhanced CS1 fluorescence was observed after treatment with $\mathrm{CuCl}_{2}$ (Fig. 3D). These findings demonstrate that the increased CS1 fluorescence observed in HEK293 cells appears to be particular to this cell type and not a general response to $\mathrm{Cu}$ supplementation in cultured cells.

(c) To examine the possibility that the $\mathrm{Cu}$ concentrations detected above reflected metal ion that had not been fully internalized, but was associated with components of the culture media or membrane, $\mathrm{M} 17$ cells treated with $\mathrm{Cu}^{\mathrm{II}}(\mathrm{gtsm})$ or $\mathrm{CuCl}_{2}$ were probed by XFM to map total cellular $\mathrm{Cu}$ distribution. The technique confirmed a significant increase in total cellular $\mathrm{Cu}$ in $\mathrm{Cu}^{\mathrm{II}}$ (gtsm)-treated cells compared to vehicle controls or treatment with $\mathrm{CuCl}_{2}$ (Fig. 4). In addition, we found no difference in $\mathrm{CS} 1$ fluorescence in cells when cells were washed after $\mathrm{Cu}$ treatment when compared to addition of $\mathrm{CS} 1$ to media containing $\mathrm{Cu}$. This indicated that the lack of CS1 fluorescence enhancement by $\mathrm{Cu}$ was not related to extracellular interaction between exogenous $\mathrm{Cu}$ and $\mathrm{CS} 1$ (thus preventing CS1 uptake by cells). 
(d) A time-course analysis was performed to determine if the observations were dependent on the period of exposure to the sources of $\mathrm{Cu}$. M17 cells were treated with $\mathrm{CuCl}_{2}$ or $\mathrm{Cu}^{\mathrm{II}}(\mathrm{gtsm})$ $(10 \mu \mathrm{M})$ followed by equimolar CS1. A higher concentration of CS1 $(10 \mu \mathrm{M})$ was used in these experiments to ensure that the sensor was not saturated. No significant increase in fluorescence was observed for periods up to $1 \mathrm{~h}$, despite parallel assessment of cellular $\mathrm{Cu}$ content by AAS, indicating that elevated total $\mathrm{Cu}$ levels were present in all treated cells (Fig. 5). Again, the majority of the fluorescence was associated with a punctate lysosomal-like appearance.

(e) As the original report employed live cell imaging, ${ }^{10}$ the behavior of both live M17 neurons and live HEK293 cells was tested. Cells were exposed to $\mathrm{Cu}^{\mathrm{II}}$ (gtsm) for $30 \mathrm{~min}$ and visualized using live cell epifluorescence imaging. In HEK293 cells, $\mathrm{Cu}^{\mathrm{II}}(\mathrm{gtsm})$ produced a significant elevation of CS1 fluorescence intensity compared to vehicle controls (Fig. 6A). The fluorescence was not as intense as in the fixed cells, but was likely due to the lower concentration of CS1 used for this study $(0.5 \mu \mathrm{M})$. This concentration was chosen after titration revealed that higher doses produced unacceptably high background fluorescence in controls lacking $\mathrm{Cu}$ treatment during live cell studies, especially in M17 cells. However, the increased CS1 fluorescence in HEK293 cells with $\mathrm{Cu}^{\mathrm{II}}$ (gtsm) (or $\mathrm{CuCl}_{2}$ ) treatment was consistent with the initial findings on live HEK293 cells, ${ }^{10,13}$ as well as the result in Fig. 2A using fixed cells. In contrast, M17 cells revealed no clear change to $\mathrm{CS} 1$ fluorescence with $\mathrm{Cu}^{\mathrm{II}}$ (gtsm) treatment compared to CS1 alone (Fig. 6B). These results indicated that the fixation process did not significantly alter the observed fluorescence behavior.

While enhancement of CS1 fluorescence with $\mathrm{Cu}$ supplementation in HEK293 cells matched that described previously (Figs 2
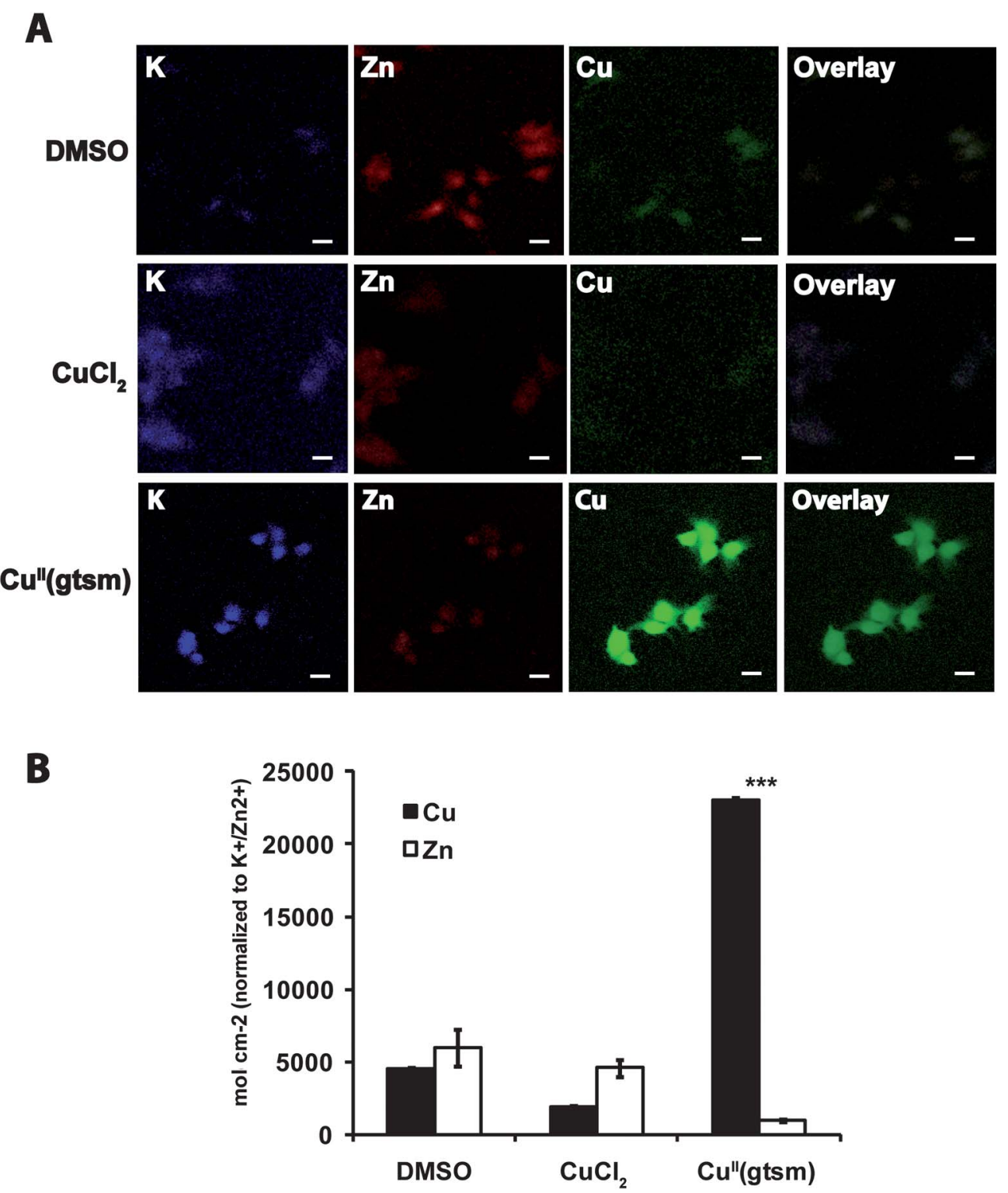

Fig. 4 XFM analysis of M17 cells treated with $\mathrm{CuCl}_{2}(100 \mu \mathrm{M})$ for $6 \mathrm{~h}$, and $\mathrm{Cu}^{\mathrm{II}}(\mathrm{gtsm})(5 \mu \mathrm{M})$ for 30 min shows that $\mathrm{Cu}^{\mathrm{II}}(\mathrm{gtsm})$ effectively delivered $\mathrm{Cu}$ into cells compared to $\mathrm{CuCl}_{2}$ (A and quantified in $\mathrm{B}$ ). ${ }^{* * *} p<0.001$ compared to vehicle control. Scale bars represent $20 \mu \mathrm{m}$ for all images. 

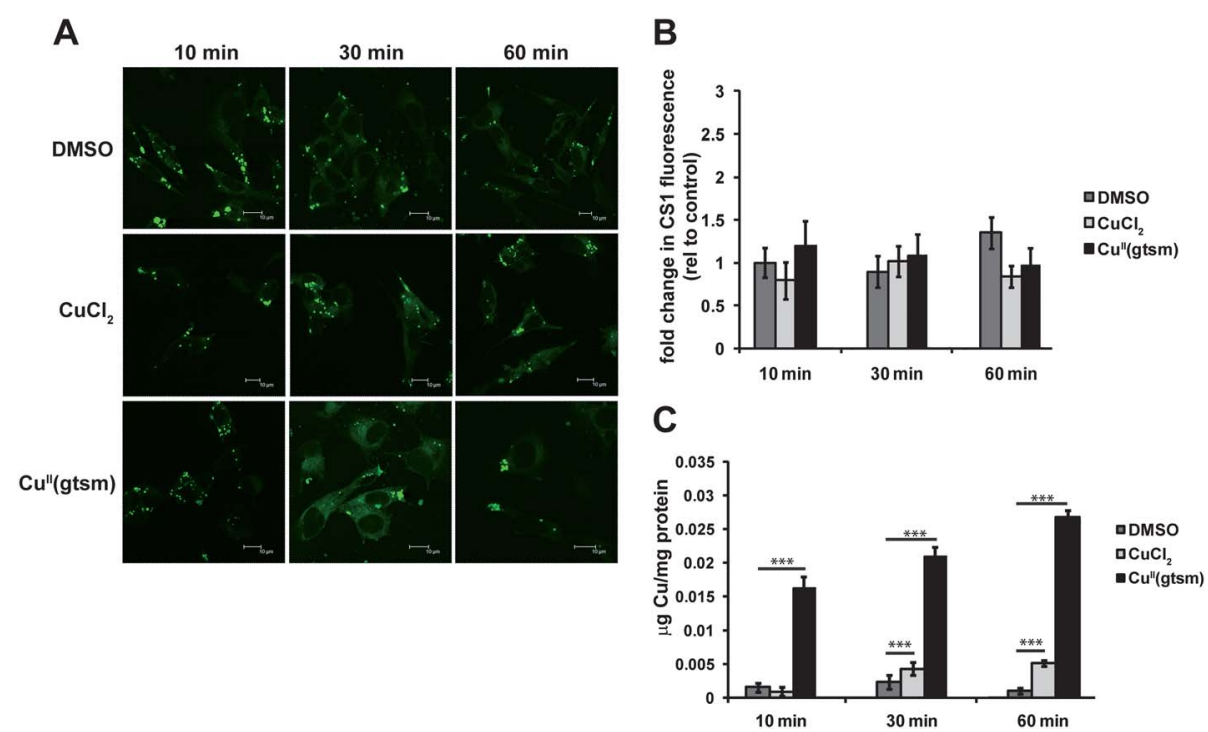

Fig. $5 \mathrm{CS} 1$ fluorescence did not increase with time in $\mathrm{CuCl}_{2}$ and $\mathrm{Cu}^{\mathrm{II}}(\mathrm{gtsm})$-treated $\mathrm{M} 17$ cells. Cells were exposed to $\mathrm{CuCl}$, or $\mathrm{Cu}$ (gtsm) $(10 \mu \mathrm{M})$ and DMSO as the vehicle control for 10,30 and $60 \mathrm{~min} .10 \mu \mathrm{M} \mathrm{CS1}$ was added to the cells for the last 5 min of the treatment period. Cells were fixed with $4 \%$ PFA and examined by confocal microscopy (A, and quantified in B). Time-dependent changes to CS1 fluorescence were not observed. Parallel measurement of cellular accumulation of $\mathrm{CuCl}_{2}$ and $\mathrm{Cu}^{\mathrm{II}}(\mathrm{gtsm})$ by AAS revealed significant increases in $\mathrm{Cu}$ accumulation in the cells compared to $\operatorname{DMSO}(\mathrm{C})(* * *)<0.001)$. Scale bars represent $10 \mu \mathrm{m}$ for all images.

and 6A), ${ }^{10,13}$ the failure to observe an effect in M17 or alternative cell lines raised questions about the nature of the enhancement.

\section{CS1 cannot sense $\mathrm{Cu}^{\mathrm{I}}$ in the presence of proteins of sub- picomolar affinities}

In view of the unexpected results described above, further characterization of the $\mathrm{Cu}^{\mathrm{I}}$ binding properties of $\mathrm{CS} 1$ was undertaken (Figs 7 and $\mathrm{S} 1-\mathrm{S} 3 \dagger$ ). In the absence of a competing $\mathrm{Cu}^{\mathrm{I}}$ ligand, titration of either $\mathrm{Cu}^{\mathrm{I}}$ or $\mathrm{Cu}^{\mathrm{II}}$ into apo-CS1 in MOPS buffer $(50 \mathrm{mM}, \mathrm{pH} 7.4)$ in the presence of a reductant induced an increase in absorbance around $540 \mathrm{~nm}\left(\Delta_{5} \varepsilon_{50} \approx 2.4 \times 10^{4} \mathrm{M}^{-1}\right.$ $\mathrm{cm}^{-1}$ ). In addition, an enhancement of fluorescence between 550 $680 \mathrm{~nm}$ upon excitation at $540 \mathrm{~nm}$ signaled $\mathrm{Cu}^{\mathrm{I}}$ binding to CS1 to yield $\mathrm{Cu}^{\mathrm{I}}-\mathrm{CS} 1$ (Figs 7A and S1A $\dagger$ ). ${ }^{10,13}$

An equivalent titration but in the presence of four equivalents of ligand Bca induced little fluorescence enhancement until about two equivalents of $\mathrm{Cu}^{\mathrm{I}}$ was added (Fig. 7A(ii)). This behavior indicated that CS1 could not compete with Bca until the latter was nearly saturated via formation of complex $\left[\mathrm{Cu}^{\mathrm{I}}(\mathrm{Bca})_{2}\right]^{3-}$ $\left(\beta_{2}=10^{17.2} \mathrm{M}^{-2}\right)$. Bca buffers free $\mathrm{Cu}^{\mathrm{I}}$ concentration within the range $10^{-12}-10^{-15} \mathrm{M}^{28,29}$ The results indicate that the $\mathrm{Cu}^{\mathrm{I}}$-binding affinity of CS1 must be weaker than picomolar, ie, $K_{\mathrm{D}}>10^{-12} \mathrm{M}$.

The above estimate was supported by similar competition experiments with the metallo-chaperone protein CopK, a bacterial periplasmic copper-binding protein whose affinity for $\mathrm{Cu}^{\mathrm{I}}$ is weaker than picomolar $\left(K_{\mathrm{D}} \approx 10^{-11} \mathrm{M}\right)$, in the absence of $\mathrm{Cu}^{\text {II }}{ }^{31}$ Competition experiments in the presence of reductant ascorbate (that eliminates the presence of $\mathrm{Cu}^{\mathrm{II}}$ ) showed that $\mathrm{CS} 1$ and $\mathrm{CopK}$ were competing for $\mathrm{Cu}^{\mathrm{I}}$ under the conditions (Fig. 7B). However, if both $\mathrm{Cu}^{\mathrm{I}}$ and $\mathrm{Cu}^{\mathrm{II}}$ are available $\left(\mathrm{Cu}^{\mathrm{II}}\right.$ plus $\mathrm{NH}_{2} \mathrm{OH}$ as weaker reductant), the protein binds both $\mathrm{Cu}^{\mathrm{I}}\left(K_{\mathrm{D}} \approx\right.$ $\left.10^{-13} \mathrm{M}\right)$ and $\mathrm{Cu}^{\mathrm{II}}\left(K_{\mathrm{D}} \approx 10^{-12} \mathrm{M}\right)$, i.e., the affinity for $\mathrm{Cu}^{\mathrm{I}}$ is increased by $\sim 100$ fold in the presence of $\mathrm{Cu}^{\mathrm{II}} .{ }^{31}$ Under these conditions, CS1 cannot compete for $\mathrm{Cu}^{\mathrm{I}}$ (Fig. S2 $\dagger$ ). Indeed, titration of one equivalent of $\mathrm{CopK}$ into a $\mathrm{Cu}^{\mathrm{I}}-\mathrm{CS} 1$ solution in the absence of ascorbate led to complete removal of $\mathrm{Cu}^{\mathrm{I}}$ from the $\mathrm{Cu}^{\mathrm{I}}-\mathrm{CS} 1$ complex (Fig. S1B $\dagger$ ). Under such non-reducing conditions, the $\mathrm{Cu}^{\mathrm{I}}$ bound by $\mathrm{CopK}$ is partially oxidized to $\mathrm{Cu}^{\mathrm{II}}$, a process driven by the enhanced cooperative binding of both $\mathrm{Cu}^{\mathrm{I}}$ and $\mathrm{Cu}^{\mathrm{II}}$ in CopK. ${ }^{31}$ The above experiments demonstrate that: (i) the $\mathrm{Cu}^{\mathrm{I}}$ affinity of $\mathrm{CS} 1$ is weaker than picomolar $\left(K_{\mathrm{D}} \approx 10^{-11} \mathrm{M}\right)$ supporting the previously reported value of $K_{\mathrm{D}}=10^{-11.4} \mathrm{M} ;{ }^{13}$ (ii) $\mathrm{Cu}^{\mathrm{I}}$ bound by $\mathrm{CS} 1$ is kinetically labile and is removed readily under a thermodynamic gradient.

Mammalian intracellular $\mathrm{Cu}^{\mathrm{I}}$-binding proteins, such as Atox1, the N-terminal domains of ATP7a and ATB7b and the metallothioneins bind $\mathrm{Cu}^{\mathrm{I}}$ with affinities that are 5-6 orders of magnitude higher than that of CS1 (smaller $K_{\mathrm{D}}$ values). ${ }^{29} \mathrm{CS} 1$ is unable to bind $\mathrm{Cu}^{\mathrm{I}}$ in the presence of these protein molecules. For example, titration of $\mathrm{Cu}^{\mathrm{I}}$ into solutions containing both CS1 and Atox1 induced a significant spectroscopic response from CS1 only after Atox 1 was saturated with more than one equivalent of $\mathrm{Cu}^{\mathrm{I}}$ (Fig. 7C). On the other hand, titration of one equivalent of Atox 1 into a $\mathrm{Cu}^{\mathrm{I}}-\mathrm{CS} 1$ solution caused immediate quenching of the enhancement of fluorescence intensity (Fig. S3 $†$ ).

These results are consistent with published data indicating that the free $\mathrm{Cu}^{\mathrm{I}}$ levels in eukaryotic cells are modulated at atto-molar levels $\left.\left(\sim 10^{-18} \mathrm{~mol} \mathrm{~L}^{-1}\right)\right)^{5-7}$ a situation clarified recently by the development of a unified system of $\mathrm{Cu}^{\mathrm{I}}$ affinities. ${ }^{29}$ There appears to be no copper in the cytosol bound weakly enough for CS1 to sense.

As discussed above, Atox 1 binds one atom of $\mathrm{Cu}^{\mathrm{I}}$ with high affinity $\left(K_{\mathrm{D}} \approx 10^{-17.4} \mathrm{M} ; \mathrm{pH} 7.0^{29}\right)$, which cannot be detected by CS1. However, CS1 reported further weak binding of 3-4 extra atoms of $\mathrm{Cu}^{\mathrm{I}}$ (note response in Fig. $7 \mathrm{C}$ ). The nature of these weakly bound secondary sites is unclear, but the active site motif $\mathrm{CXXC}$ is known to bind extra atoms of $\mathrm{Cu}^{\mathrm{I}}$ with low affinity and 


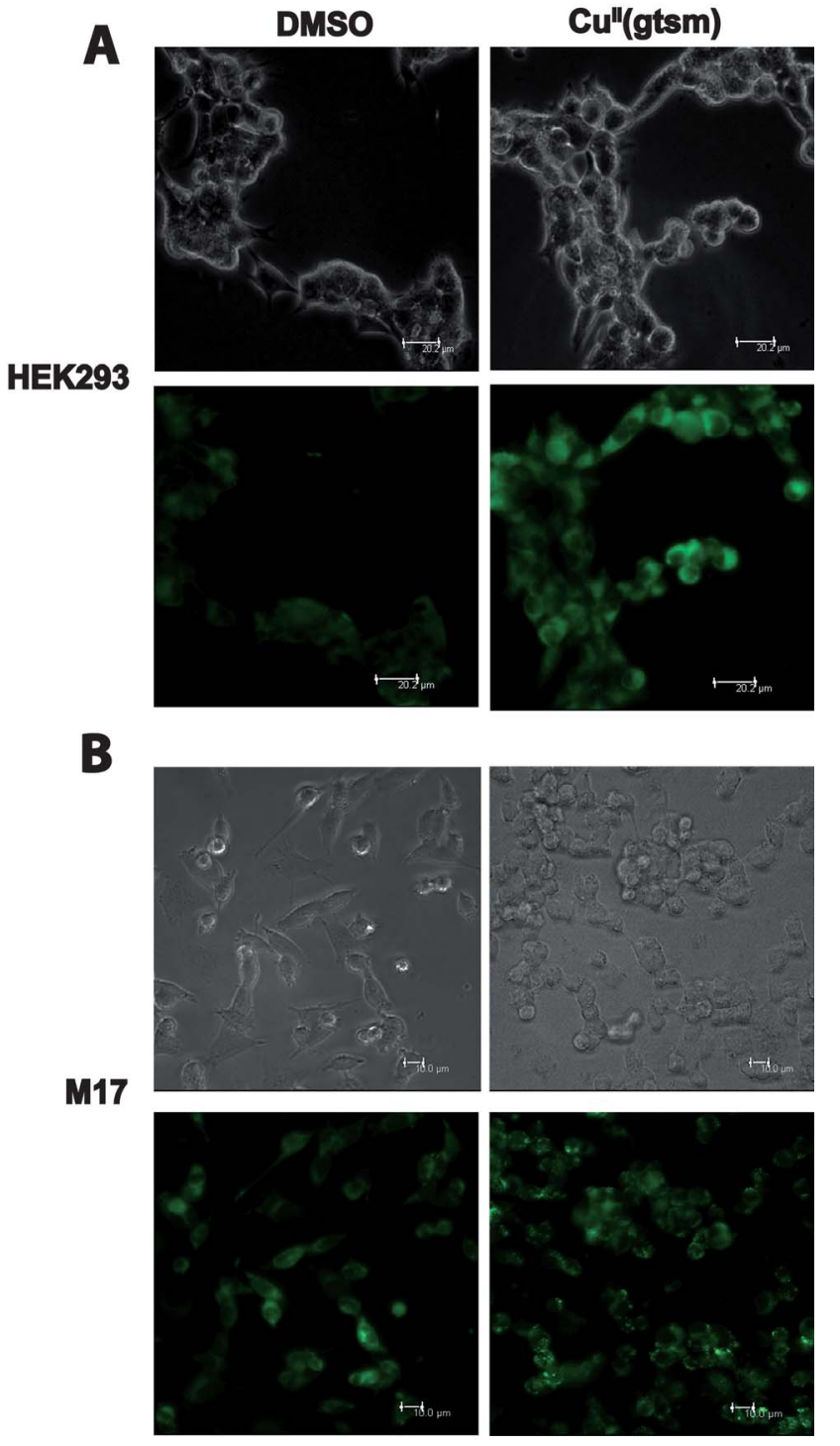

Fig. 6 Live cell imaging of CS1. (A) Fluorescence of CS1 was enhanced in live HEK293 cells after treatment with $\mathrm{Cu}^{\mathrm{II}}(\mathrm{gtsm})$ compared to the vehicle control (DMSO). (B) No change in CS1 fluorescence was observed in $\mathrm{M} 17$ cells treated with $\mathrm{Cu}^{\mathrm{II}}(\mathrm{gtsm})$. Cells were treated with $\mathrm{Cu}^{\mathrm{II}}(\mathrm{gtsm})$ for $30 \mathrm{~min}$ and visualized using live cell epifluorescence imaging. Scale bars represent $10 \mu \mathrm{m}$ for all images.

there is a third Cys residue which may also be involved in weak $\mathrm{Cu}^{\mathrm{I}}$ binding. ${ }^{2}$ Apparently, CS1 can compete for these weaklybound $\mathrm{Cu}^{\mathrm{I}}$ atoms from Atox1 or can form fluorescent ternary complexes.

However, Atox 1 will not be saturated with $\mathrm{Cu}^{\mathrm{I}}$ under normal cellular conditions and CS1 is clearly not able to access copper in the cytosol unless the cell is overwhelmed by a toxic level of the metal ion. These findings indicate that the elevated CS1 fluorescence observed only in HEK293 cells is probably related to indirect effects of $\mathrm{Cu}$ in this cell type, which may not occur as readily in other cell types. Interestingly, a $\mathrm{Cu}^{\mathrm{I}}$ probe CTAP-2 with a similar sub-picomolar affinity to that of CS1 is reported to detect $\mathrm{Cu}^{\mathrm{I}}$ bound to Atox 1 by in-gel techniques. ${ }^{35}$ The nature of the detected metal ion remains to be defined, but is likely to be the weakly-bound secondary sites and not the primary site.
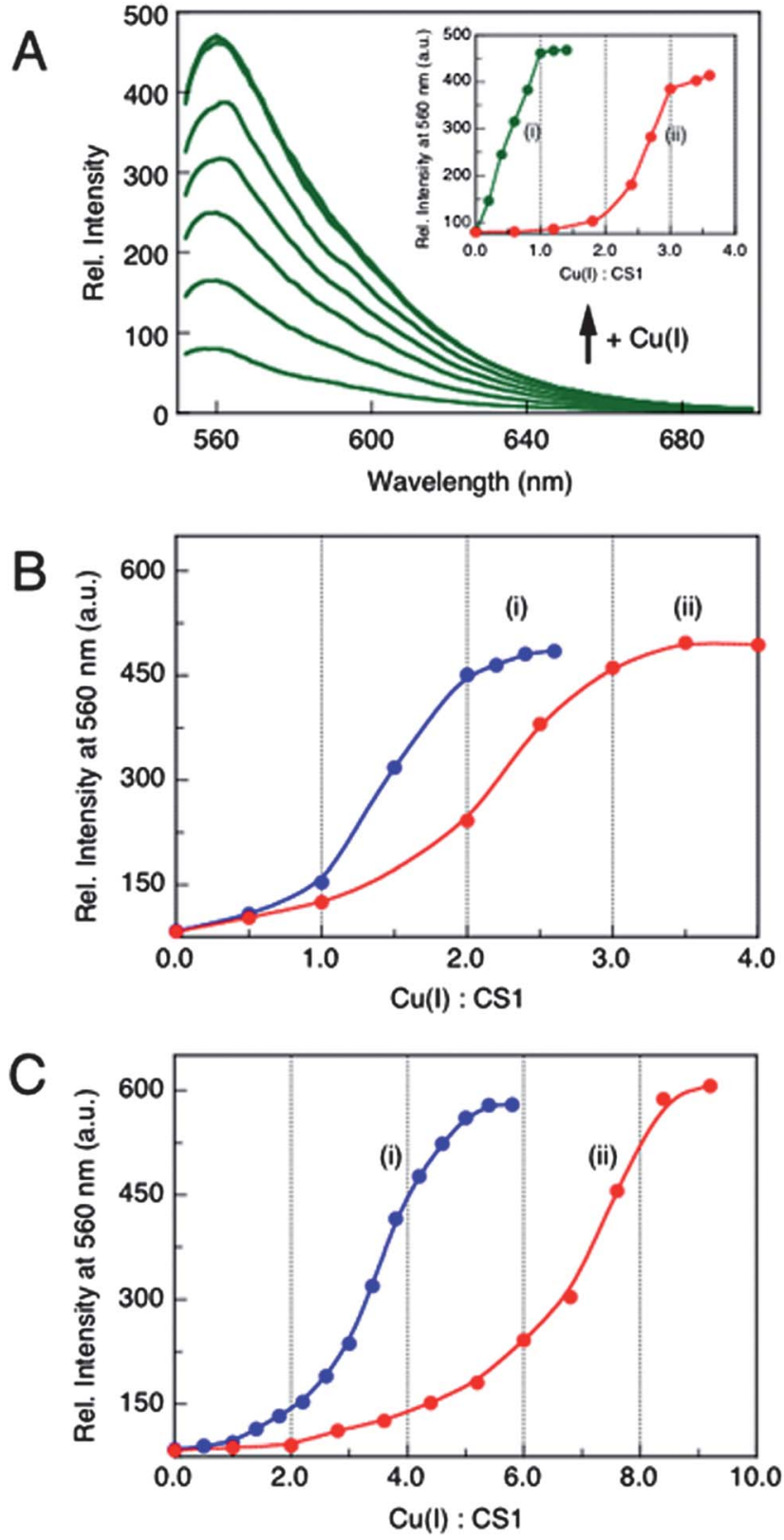

Fig. 7 Fluorescence response (excitation: $540 \mathrm{~nm}$ ) upon titration of $\left[\mathrm{Cu}^{\mathrm{I}}(\mathrm{MeCN})_{4}\right]^{+}$solution into CS1 $(2.0 \mu \mathrm{M})$ in MOPS buffer $(50 \mathrm{mM}, \mathrm{pH}$ 7.4; ascorbate $1.0 \mathrm{mM}$ ) in the presence of $\mathrm{Cu}^{\mathrm{I}}$-binding ligands. (A) Control titration in the absence of competing ligands. Inset (i) is a plot of $\mathrm{F}_{560}$ versus $\mathrm{Cu}^{\mathrm{I}}: \mathrm{CS} 1$ ratio for the control titration and inset (ii) is an equivalent titration in the presence of four equivalents of Bca $(8.0 \mu \mathrm{M})$. Note, the final fluorescence enhancement of CS1 in the presence of Bca was smaller than that of the control titration due to an inner filter effect of the chromophoric complex $\left[\mathrm{Cu}^{\mathrm{I}}(\mathrm{Bca})_{2}\right]^{3-}$ (see the dashed trace in Fig. S1A $\dagger$ ). (B and C): Plots of $\mathrm{F}_{560}$ versus $\mathrm{Cu}^{\mathrm{I}}: \mathrm{CS} 1$ for the titration of CS1 $(2.0 \mu \mathrm{M})$ in the presence of one (i) and two (ii) equivalents of (B) the bacterial periplasmic $\mathrm{Cu}^{\mathrm{I}}$ binding protein $\mathrm{CopK}$ and $(\mathrm{C})$ the Atox 1 protein.

\section{CS1 localizes to lysosomes}

A lysosomal-like staining pattern for CS1 fluorescence was observed in most cells and particularly in $\mathrm{Cu}$-supplemented cells (Figs 2A, 3A-B, 5A). A fluorescent lysosomal marker was 
applied to document this effect. Clear co-localization of CS1 and Lysotracker Yellow HCK-123 (Fig. 1) was observed in Cu-supplemented M17 cells (Fig. 8A), but there was no co-localization of CS1 and $\mathrm{NBDC}_{6}$-ceramide, the fluorescent Golgi complex marker (Fig. 8B, arrows). These observations indicate that CS1 fluorescence was predominantly associated with lysosomes. It is not certain why CS1 localizes to the lysosome although this could be related to structural similarities between CS1 and Lysotracker. Moreover, the common cellular response for xenobiotics is trafficking to lysosomes for degradation, storage or efflux. ${ }^{36}$

As $\mathrm{pH} \approx 4$ in the lysosome, an understanding of the behavior of the fluorescence of $\mathrm{CS} 1$ as a function of $\mathrm{pH}$ was required. While the fluorescence emission of CS1 $(2.0 \mu \mathrm{M})$ is enhanced upon binding one equivalent $\mathrm{Cu}^{\mathrm{I}}$ within the $\mathrm{pH}$ range $7.4-4.0$ (red, blue traces in Fig. 8C-E), the intensity of fluorescence emission of both apo-CS1 and $\mathrm{Cu}^{\mathrm{I}}-\mathrm{CS} 1$ in vitro does not vary significantly due to changes in $\mathrm{pH}$ (range 7.4-4.0). However, the affinity of $\mathrm{GSH}\left(\sim 10^{-3} \mathrm{M}\right.$ in the cytosol) for $\mathrm{Cu}^{\mathrm{I}}$ is expected to depend upon $\mathrm{pH}$, in parallel with relative access to the ligating thiolate form. ${ }^{37}$ The relative affinities of GSH and CS1 were examined as a function of $\mathrm{pH}$ as an indirect probe of CS1 behavior.

Progressive titration of $\mathrm{GSH}$ into a solution of $\mathrm{Cu}^{\mathrm{I}}-\mathrm{CS} 1$ diminished the intensity of the emission (green traces in Fig. 8CE). At $\mathrm{pH} 7.4$, a relative concentration of $\mathrm{GSH}: \mathrm{Cu}^{\mathrm{I}}-\mathrm{CS} 1$ as low as $5: 2$ was enough to completely remove the metal ion from the $\mathrm{Cu}^{\mathrm{I}}$-CS1 complex (Fig. 8C), which is consistent with the fact that
GSH buffers free $\mathrm{Cu}^{\mathrm{I}}$ concentrations in the sub-picomolar range. ${ }^{29}$ However, at $\mathrm{pH} 6.0$, a higher relative concentration of GSH is required to remove $\mathrm{Cu}^{\mathrm{I}}$ from $\mathrm{Cu}^{\mathrm{I}}-\mathrm{CS} 1$ and, at $\mathrm{pH} 4.0$, CS1 can compete effectively with GSH for $\mathrm{Cu}^{\mathrm{I}}$ (Fig. 8D and E).

It can be concluded that $\mathrm{CS} 1$ cannot compete for $\mathrm{Cu}^{\mathrm{I}}$ with the abundant redox buffer GSH under normal cellular conditions $(\mathrm{pH}>6)$, but can compete at $\mathrm{pH} 4$. As $\mathrm{CS} 1$ fluorescence was predominantly associated with lysosomes (Fig. 8A), possible interpretations include (i) that it derives from the significant 'background' intensity arising from an enhanced concentration of apo-CS1 in this organelle; (ii) the probe gaining access to $\mathrm{Cu}^{\mathrm{I}}$ made available via recycling of nutrient $\mathrm{Cu}$ in the acidic lysosome. Alternatively, as the source of the fluorescence enhancement in CS1 is the conversion of the tertiary nitrogen into a quaternary center (see Fig. 1), a different activation mechanism may operate under conditions of acid hydrolysis (e.g. reaction of the tertiary nitrogen with a cell metabolite or formation of ternary metal complexes). ${ }^{38,39}$

\section{Elevated CS1 fluorescence was observed in M17 cells subjected to redox or acid-base stress}

The predictions concerning the relative affinities of CS1 and GSH under normal cellular conditions led to application of the compound buthionine sulfoximine (BSO), which is able to decrease GSH levels in cultured cells. Overnight exposure of M17 cells to BSO $(5 \mathrm{mM})$ caused an approximately $80 \%$ decrease in
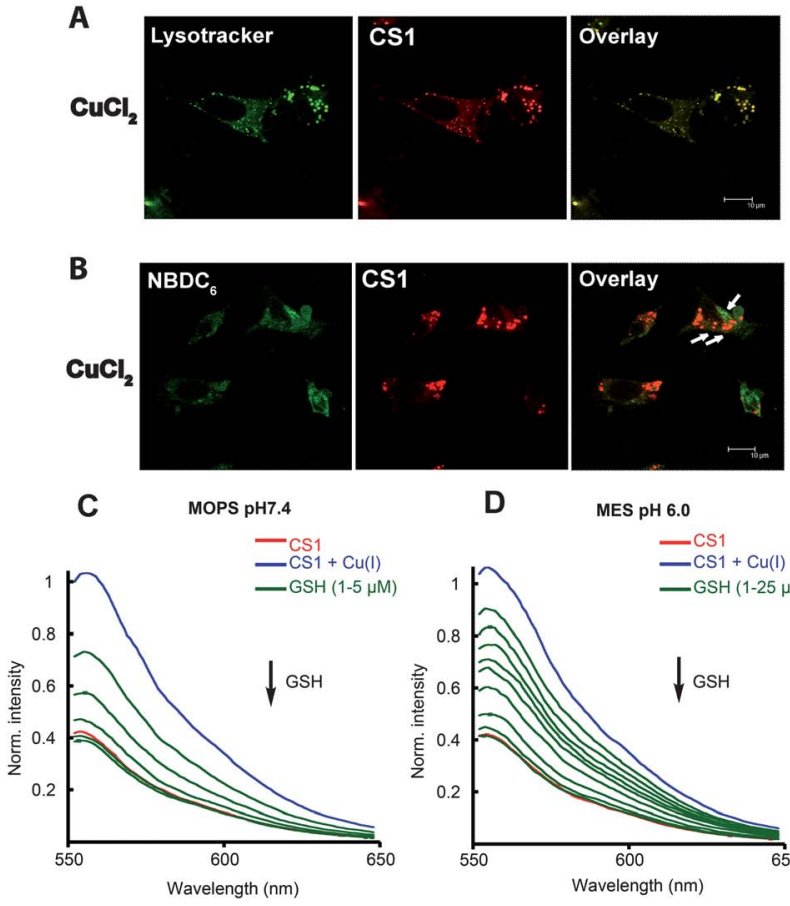

D

MES $\mathrm{pH} 6.0$
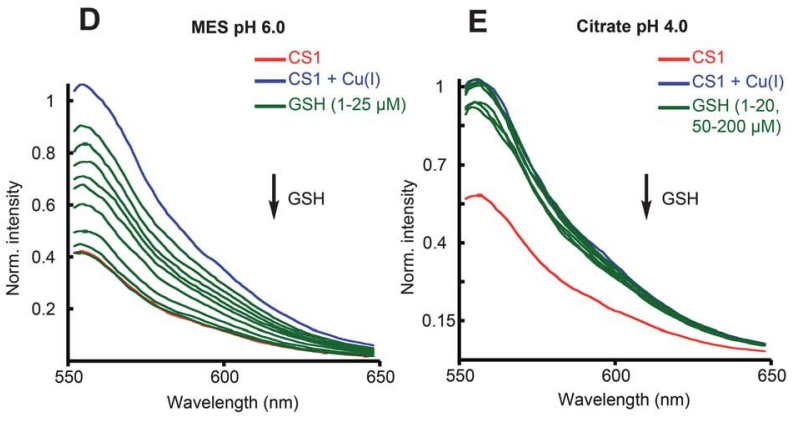

Fig. 8 (A) CS1 colocalized to lysosomes in M17 cells. Cells were co-treated with $\mathrm{CuCl}_{2}(10 \mu \mathrm{M})$ and Lysotracker Yellow (75 nM) for $30 \mathrm{~min}$ and $\mathrm{CS} 1$ $(500 \mathrm{nM})$ was added for 5 min before cells were examined by confocal microscopy. CS1 was artificially colored red and Lysotracker Yellow was artificially colored green to aid visualization. (B) CS1 did not colocalize to the Golgi complex in $\mathrm{M} 17$ cells treated with $\mathrm{CuCl}_{2}$. Cells were co-treated with $\mathrm{CuCl}_{2}(100 \mu \mathrm{M})$ and $\mathrm{CS} 1(500 \mathrm{nM})$ before staining for the Golgi complex using NBDC 6 -ceramide $(5 \mu \mathrm{M})$ and examination by confocal microscopy. CS1 was artificially colored red and $\mathrm{NBDC}_{6}$-ceramide was artificially colored green in these images. Arrows show the lack of co-localization. Scale bars represent $10 \mu \mathrm{m}$ for all images. (C-E) Comparison of the fluorescence spectra of $2 \mu \mathrm{M}$ CS1 (red) in the presence of $2 \mu \mathrm{M} \mathrm{Cu} \mathrm{C}^{\mathrm{I}}(\mathrm{blue})$ at pH $7.4(20 \mathrm{mM}$ MOPS buffer) (C); pH 6.0 (20 mM MES buffer) (D) and pH 4.0 (20 mM citrate buffer) (E). Response to treatment with GSH is shown in (green): CS1 fluorescence induced by $\mathrm{Cu}^{\mathrm{I}}$ was quenched by the presence of $\mathrm{GSH}$ at $\mathrm{pH} 7.4$ and $\mathrm{pH}$ 6.0. 
GSH levels compared to control cells (Fig. 9A). A significant enhancement of CS1 fluorescence was observed in all GSHdepleted cells, including untreated controls and $\mathrm{Cu}$-supplemented cells (Fig. 9B and C). Intriguingly, parallel AAS analysis revealed that cellular $\mathrm{Cu}$ levels were decreased by BSO treatment in cells previously exposed to $\mathrm{Cu}$ (Fig. 9D), presumably a consequence of a protective response to $\mathrm{Cu}$ toxicity. ${ }^{40}$ Again, the source of fluorescence enhancement cannot be assigned with confidence, but is likely to be associated with the loss of cellular redox homeostasis and increased cell stress from impaired $\mathrm{Cu}$ homeostasis. ${ }^{41}$ As canvassed above, access to $\mathrm{Cu}^{\mathrm{I}}$ due to impaired $\mathrm{Cu}$ homeostasis or an alternative activation mechanism must be considered.

To test if the observed fluorescence enhancement in HEK293 cells but not in M17 or U87MG cells arises from different levels of GSH among these cell lines, its levels in all three cell lines used in this work were estimated. The cellular GSH content did not differ significantly, either under basal conditions or after treatment with $100 \mu \mathrm{M} \mathrm{CuCl}_{2}$. These results again suggest that other factors besides GSH levels alone may affect the differential CS1 fluorescence seen in these cell lines upon exposure to $\mathrm{Cu}$.

The identification of lysosomal CS1 fluorescence (see above) suggested that the fluorescence may be modulated by the acidbase properties of cells. The influence of variation of effective cell $\mathrm{pH}$ was investigated by treating M17 cells with the vacuolar $\mathrm{H}^{+}$ ATPase inhibitor bafilomycin (Baf). This treatment inhibits acidification of organelles, such as synaptic vesicles and lysosomes, leading to an accumulation of protons in the cytosol and subsequent cytosolic acidification (lower effective $\mathrm{pH}$ ). ${ }^{42,43}$ As the acid-base nature of these organelles is important for normal function, prevention of vesicle acidification by Baf causes concomitant inhibition of vesicle maturation and subsequent cell stress. ${ }^{42}$ A strong enhancement of CS1 fluorescence was observed in Baf-treated M17 cells (Fig. 9E, quantified in 9F), but there was no parallel change in cellular $\mathrm{Cu}$ levels, as detected by AAS. As

A

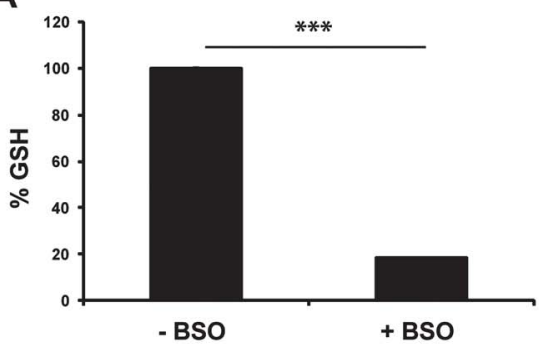

B

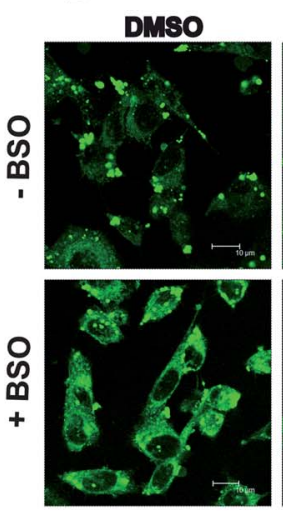

E

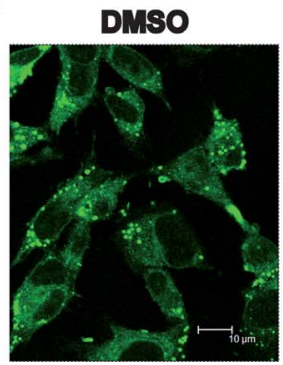

$\mathrm{CuCl}_{2}$
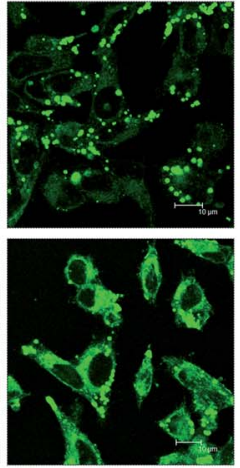

Cul(gtsm)
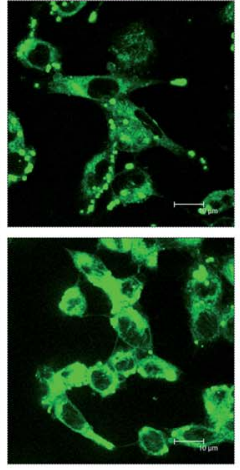

C

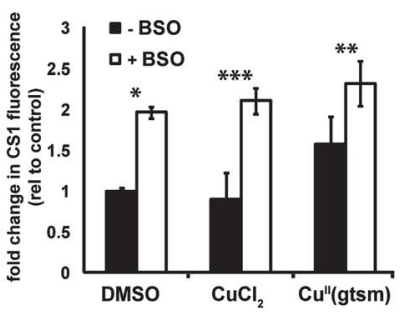

D

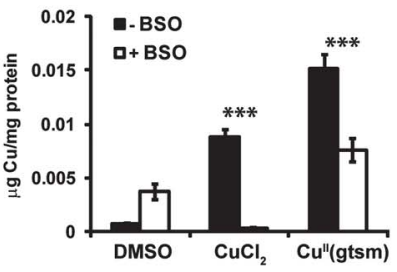

F
$100 \mathrm{nM}$ Baf

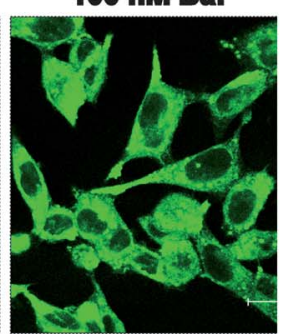

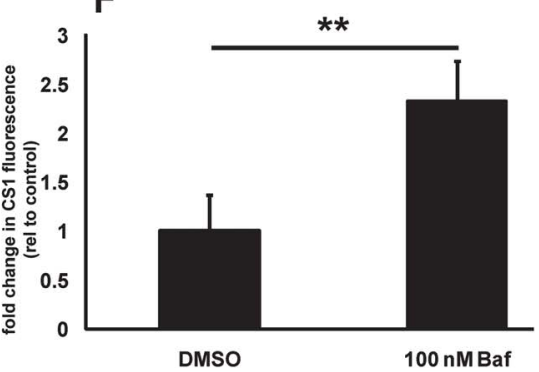

Fig. 9 Effect of GSH depletion in M17 cells treated overnight with BSO (5 mM) compared with vehicle control on glutathione content (A) and CS1 fluorescence (B). Increased CS1 fluorescence was observed in Cu-treated and control cells pre-treated with BSO (B and quantitated in C). Parallel cellular $\mathrm{Cu}$ levels were determined by AAS (D). M17 cells were treated with DMSO as the vehicle control, $\mathrm{CuCl}_{2}(100 \mu \mathrm{M}$ for $6 \mathrm{~h})$ or $\mathrm{Cu}$ (gtsm) $(5 \mu \mathrm{M}$ for 30 $\mathrm{min}$ ) before the inclusion of CS1 for the last $5 \mathrm{~min}$ of the total treatment time. $\left({ }^{*} p<0.05,{ }^{* *} p<0.01,{ }^{* * *} p<0.001\right.$ between BSO treated and untreated cells). (E) CS1 fluorescence in M17 cells with bafilomycin (Baf) treatment (100 nM) compared to DMSO as the vehicle control (quantitated in F). 
discussed above, enhancement of CS1 fluorescence was not observed in vitro at low $\mathrm{pH}$. The source of the enhanced CS1 fluorescence in Baf-treated cells is therefore not certain, but may be associated with cytosolic accumulation of CS1 due to altered vesicle $\mathrm{pH}$ or increased access to cellular $\mathrm{Cu}$ stores.

\section{Summary}

$\mathrm{CS} 1$ and its related forms are reported as $\mathrm{Cu}$ sensors based on a thioether-rich $\mathrm{NS}_{4}$ (potentially pentadentate) ligand tethered to a BODIPY fluorophore (Fig. 1). The ligand is selective for $\mathrm{Cu}^{\mathrm{I}}$ with picomolar affinity over a number of other biologically relevant metal ions. ${ }^{10,13}$ Its affinity for $\mathrm{Cu}^{\mathrm{I}}$ was confirmed independently in this work on a unified scale. ${ }^{29}$ The free ligand is itself fluorescent, but upon binding of $\mathrm{Cu}^{\mathrm{I}}\left(\mathrm{d}^{10}\right)$, there is a significant enhancement of the fluorescent intensity.

CS1 has been applied to the detection of 'exchangeable' $\mathrm{Cu}$ pools in HEK 293 cells. ${ }^{10,13}$ A number of alternative synthetic $\mathrm{Cu}$ sensors have been reported. ${ }^{7,38,44,45}$ Different forms of the sensor $\mathrm{CS} 1$ have been applied to measure basal $\mathrm{Cu}^{\mathrm{I}}$ levels in both secondary cells and rat hippocampal neurons. ${ }^{11,12,14}$

The present study was able to reproduce the initial findings on HEK293 cells supplemented with $\mathrm{CuCl}_{2} \cdot{ }^{10}$ However, an increased CS1 signal was not observed in M17 neuronal-, U87MG glial-like cells or additional cell lines exposed to $\mathrm{CuCl}_{2}$ or $\mathrm{Cu}^{\mathrm{II}}(\mathrm{gtsm})$ that delivers high doses of $\mathrm{Cu}$ to the cells (as confirmed by AAS). These findings raise questions about the nature of CS1 sensing. Clearly, CS1 does not routinely detect large increases in cellular $\mathrm{Cu}$ in all cell types.

Associated findings include:-

(a) The affinity of $\mathrm{CS} 1$ for $\mathrm{Cu}^{\mathrm{I}}$ is too weak to allow for competition with the $\mathrm{Cu}$-binding proteins that maintain homeostasis at atto-molar levels under normal cellular conditions. It cannot even compete with the endogenous redox buffer $\mathrm{GSH}$, which buffers $\mathrm{Cu}^{\mathrm{I}}$ at pico-molar levels.

(b) CS1 fluorescence localizes to the lysosomes or lysosomallike structures in the three cell types examined in this work. Its fluorescence appears to be enhanced under the acidic conditions present in that organelle. Localization of CS1 to recycling vesicular pathways could also be promoted by the propensity of the compound to form colloidal aggregates in aqueous solution as reported recently. ${ }^{35}$

(c) Cytosolic enhancement of CS1 fluorescence was observed in M17 neuronal cells stressed by variation of intracellular GSH levels or proton availability. The enhancement does not correlate with cellular $\mathrm{Cu}$ levels.

It is clear that cytoplasmic CS1 fluorescence can be enhanced by supplementing HEK293 cells with $\mathrm{Cu}$, as reported previously ${ }^{10}$ and confirmed here (Fig. 2). However, our data strongly suggests that this effect, and similar changes to CS1 fluorescence in other cell types, needs to be interpreted with caution. Changes to effective cellular $\mathrm{pH}$, lysosomal activity or GSH levels all seem to affect cellular CS1 fluorescence, both in the presence and absence of direct increases in cellular $\mathrm{Cu}$ levels. The actual intracellular levels of CS1 could also vary depending on the cell type.

Recent path-finding development of probes for intra-cellular $\mathrm{Cu}$ and other metal ions have excited the promise of access to the coordination chemistry of cells in real time. The challenge now is to move the field to the next level of sophistication. Necessary aspects of this evolution will encompass:

(a) inclusion of multiple controls to confirm detection of the ion of interest in cell cytoplasms and organelles;

(b) careful definition of the experimental window that differentiates minor perturbation of cell chemistry from imposition of major stress.

\section{Abbreviations}

$\begin{array}{ll}\text { AAS } & \text { atomic absorption spectroscopy } \\ \text { Baf } & \text { bafilomycin } \\ \text { Bca } & \text { Bicinchoninic acid } \\ \text { BODIPY } & \text { borondipyrromethene-based fluorophore } \\ \text { BSO } & \text { buthionine sulfoximine } \\ \text { CS1 } & \text { Cu sensor number one } \\ \text { GSH } & \text { glutathione } \\ \text { PFA } & \text { paraformaldehyde } \\ \text { SOD } & \text { superoxide dismutase } \\ \text { XFM } & \text { X-ray fluorescence microscopy. }\end{array}$

\section{Acknowledgements}

This work was supported by funding from the National Health and Medical Research Council of Australia, the Australian Research Council and funds from the CSIRO OCE Postdoctoral Fellowship Program (SAJ). Aspects of this research were undertaken on the X-ray Fluorescence Microscopy beamline at the Australian Synchrotron. We would like to thank Prof. James Camakaris, Department of Genetics, The University of Melbourne for his valuable suggestions and input into this work. We thank Assoc. Prof. Andrew Hill and Dr Percy Chu, Department of Biochemistry and Molecular Biology, and Bio21 Institute, The University of Melbourne for help with live cell imaging. We also thank Dr Sharon La Fontaine, Dr Roxana Llanos and $\mathrm{Mr}$ Kenny Tran of Deakin University, Victoria, Australia for assistance with AAS, and Jens Brose and Lee Xin Chong of the University of Melbourne for isolation of Atox1 and CopK proteins.

\section{References}

1 I. Bremner, Am. J. Clin. Nutr., 1998, 67, 1069S-1073S.

2 M. Zimmermann, O. Clarke, J. M. Gulbis, D. W. Keizer, R. S. Jarvis, C. S. Cobbett, M. G. Hinds, Z. Xiao and A. G. Wedd, Biochemistry, 2009, 48, 11640-11654.

3 N. J. Robinson and D. R. Winge, Аnпи. Rev. Biochem., 2010, 79, 537562.

4 J. R. Prohaska and A. A. Gybina, J. Nutr., 2004, 134, 1003-1006.

5 T. D. Rae, P. J. Schmidt, R. A. Pufahl, V. C. Culotta and T. V. O'Halloran, Science, 1999, 284, 805-808.

6 L. A. Finney and T. V. O'Halloran, Science, 2003, 300, 931-936.

7 S. V. Wegner, F. Sun, N. Hernandez and C. He, Chem. Commun., 2011, 47, 2571-2573.

8 S. La Fontaine and J. F. Mercer, Arch. Biochem. Biophys., 2007, 463, 149-167.

9 T. Peled, E. Glukhman, N. Hasson, S. Adi, H. Assor, D. Yudin, C. Landor, J. Mandel, E. Landau, E. Prus, A. Nagler and E. Fibach, Exp. Hematol., 2005, 33, 1092-1100.

10 E. W. Miller, L. Zeng, D. W. Domaille and C. J. Chang, Nat. Protoc., 2006, 1, 824-827. 
11 D. W. Domaille, L. Zeng and C. J. Chang, J. Am. Chem. Soc., 2010, 132, 1194-1195.

12 S. C. Dodani, D. W. Domaille, C. I. Nam, E. W. Miller, L. A. Finney, S. Vogt and C. J. Chang, Proc. Natl. Acad. Sci. U. S. A., 2011, 108, 5980-5985.

13 L. Zeng, E. W. Miller, A. Pralle, E. Y. Isacoff and C. J. Chang, J. Am. Chem. Soc., 2006, 128, 10-11.

14 S. C. Dodani, S. C. Leary, P. A. Cobine, D. R. Winge and C. J. Chang, J. Am. Chem. Soc., 2011, 133, 8606-8616.

15 P. S. Donnelly, A. Caragounis, T. Du, K. M. Laughton, I. Volitakis, R. A. Cherny, R. A. Sharples, A. F. Hill, Q. X. Li, C. L. Masters, K. J. Barnham and A. R. White, J. Biol. Chem., 2008, 283, 4568-4577.

16 P. J. Crouch, L. W. Hung, P. A. Adlard, M. Cortes, V. Lal, G. Filiz, K. A. Perez, M. Nurjono, A. Caragounis, T. Du, K. M. Laughton, I. Volitakis, A. I. Bush, Q.-X. Li, C. L. Masters, R. Cappai, R. A. Cherny, P. S. Donnelly, K. J. Barnham and A. R. White, Proc. Natl. Acad. Sci. U. S. A., 2009, 106, 381-386.

17 J. L. Dearling, J. S. Lewis, D. W. McCarthy, M. J. Welch and P. J. Blower, Chem. Commun., 1998, 2531.

18 J. L. Dearling, J. S. Lewis, G. E. Mullen, M. J. Welch and P. J. Blower, JBIC, J. Biol. Inorg. Chem., 2002, 7, 249-259.

19 Z. Xiao, P. S. Donnelly, M. Zimmermann and A. G. Wedd, Inorg. Chem., 2008, 47, 4338-4347.

20 B. M. Paterson and P. S. Donnelly, Chem. Soc. Rev., 2011, 40, 30053018.

21 B. A. Gingras, T. Suprunchuk and C. H. Bayley, Can. J. Chem., 1962, 40, 1053.

22 P. J. Blower, T. C. Castle, A. R. Cowley, J. R. Dilworth P. S. Donnelly, E. Labisbal, F. E. Sowrey, S. J. Teat and M. J. Went, Dalton Trans., 2003, 4416-4425.

23 H. Beraldo, L. P. Boyd and D. X. West, Transition Met. Chem., 1998, 23, 67-71.

24 S. A. James, D. E. Myers, M. D. de Jonge, S. Vogt, C. G. Ryan, B. A. Sexton, P. Hoobin, D. Paterson, D. L. Howard, S. C. Mayo, M. Altissimo, G. F. Moorhead and S. W. Wilkins, Anal. Bioanal. Chem., 2011, 401, 853-864.

25 C. G. Ryan, D. P. Siddons, R. Kirkham, P. A. Dunn, A. Kuczewski, G. Moorhead, G. De Geronimo, D. J. Paterson, M. D. de Jonge, R. M. Hough, M. J. Lintern, D. L. Howard, P. Kappen, and J. Cleverley, Proceedings of International Conference on X-ray Optics and Microanalysis, Karlsruhe, AIP Conference Series 2010, pp. 9-11.

26 C. G. Ryan, R. Kirkham, R. M. Hough, B. E. Etschmann, G. Moorhead, M. J. Lintern, D. P. Siddons, M. D. de Jonge, D. Paterson, G. De Geronimo, D. Howard, P. Kappen and
J. Cleverley, Nucl. Instrum. Methods Phys. Res., Sect. A, 2010, 619, $37-43$.

27 A. Carmona, G. Deves and R. Ortega, Anal. Bioanal. Chem., 2008, 390, 1585-1594.

28 Z. Xiao and A. G. Wedd, Nat. Prod. Rep., 2010, 27, 768-789.

29 Z. Xiao, J. Brose, S. Schimo, S. M. Ackland, S. La Fontaine and A. G. Wedd, J. Biol. Chem., 2011, 286, 11047-11055.

30 G. L. Ellman, Arch. Biochem. Biophys., 1959, 82, 70-77.

31 L. X. Chong, M. R. Ash, M. J. Maher, M. G. Hinds, Z. Xiao and A. G. Wedd, J. Am. Chem. Soc., 2009, 131, 3549-3564.

32 K. A. Price, P. J. Crouch, I. Volitakis, B. M. Paterson, S. C. Lim, P. S. Donnelly and A. R. White, Inorg. Chem., 2011, 50, 9594-605.

33 L. W. Hung, V. L. Villemagne, L. Cheng, N. A. Sherratt, S. Ayton, A. R. White, P. J. Crouch, S. C. Lim, S. L. Leong, S. Wilkins, J. George, B. Roberts, C. L. Pham, F. C. K. Chiu, D. M. Shakelford, A. K. Powell, C. L. Masters, A. I. Bush, G. O'Keefe, J. G. Culvenor, R. Cappai, R. A. Cherny, P. S. Donnelly, A. F. Hill, D. I. Finkelstein and K. J. Barnham, J. Exp. Med., 2012, in press.

34 C. P. Soon, P. S. Donnelly, B. J. Turner, L. W. Hung, P. J. Crouch, N. A. Sherratt, J. L. Tan, N. K. Lim, L. Lam, L. Bica, S. Lim, J. L. Hickey, J. Morizzi, A. Powell, D. I. Finkelstein, J. G. Culvenor, C. L. Masters, J. Duce, A. R. White, K. J. Barnham and Q. X. Li, J. Biol. Chem., 2011, 286, 44035-44.

35 M. T. Morgan, P. Bagchi and C. J. Fahrni, J. Am. Chem. Soc., 2011, 133(40), 15906-9.

36 A. Ciechanover, Biochim. Biophys. Acta., 2012, 1824, 3-13.

37 A. Badarau and C. J. Dennison, J. Am. Chem. Soc., 2011, 133, 29832988.

38 A. F. Chaudhry, M. Verma, M. T. Morgan, M. M. Henary, N. Siegel, J. M. Hales, J. W. Perry and C. J. Fahrni, J. Am. Chem. Soc., 2010, 132, 737-747.

39 Wojciech Bal, personal communication, 2011.

40 W. C. Singleton, K. T. McInnes, M. A. Cater, W. R. Winnall, R. McKirdy, Y. Yu, P. E. Taylor, B. X. Ke, D. R. Richardson, J. F. Mercer and S. La Fontaine, J. Biol. Chem., 2010, 285, 2711127121.

41 A. R. White and R. Cappai, J. Neurosci. Res., 2003, 71, 889-897.

42 M. Forgac, Physiol. Rev., 1989, 69, 765-796.

43 J. M. Cordeiro, P. P. Goncalves and Y. Dunant, J. Physiol., 2011, 589, 149-167.

44 L. Yang, R. McRae, M. M. Henary, R. Patel, B. Lai, S. Vogt and C. J. Fahrni, Proc. Natl. Acad. Sci. U. S. A., 2005, 102, 11179-11184.

45 A. F. Chaudhry, S. Mandal, K. I. Hardcastle and C. J. Fahrni, Chem. Sci., 2011, 2, 1016-1024. 